\title{
Increased sulfate availability in saline water promotes hydrogen sulfide production in fish organic waste
}

\author{
Letelier-Gordo, Carlos Octavio; Aalto, Sanni-Leea Hellevi; Suurnäkki, Suvi; Pedersen, Per Bovbjerg
}

Published in:

Aquacultural Engineering

Link to article, DOI:

10.1016/j.aquaeng.2020.102062

Publication date:

2020

Document Version

Peer reviewed version

Link back to DTU Orbit

Citation (APA):

Letelier-Gordo, C. O., Aalto, S-L. H., Suurnäkki, S., \& Pedersen, P. B. (2020). Increased sulfate availability in saline water promotes hydrogen sulfide production in fish organic waste. Aquacultural Engineering, 89, [102062]. https://doi.org/10.1016/j.aquaeng.2020.102062

\section{General rights}

Copyright and moral rights for the publications made accessible in the public portal are retained by the authors and/or other copyright owners and it is a condition of accessing publications that users recognise and abide by the legal requirements associated with these rights.

- Users may download and print one copy of any publication from the public portal for the purpose of private study or research.

- You may not further distribute the material or use it for any profit-making activity or commercial gain

- You may freely distribute the URL identifying the publication in the public portal 
See discussions, stats, and author profiles for this publication at: https://www.researchgate.net/publication/339131967

\section{Increased sulfate availability in saline water promotes hydrogen sulfide production in fish organic waste}

Article in Aquacultural Engineering · February 2020

DOI: 10.1016/.jaquaeng.2020.102062

CITATIONS

15

4 authors, including:

Carlos Octavio Letelier-Gordo

Technical University of Denmark

11 PUblications 126 CITATIONS

SEE PROFILE
READS

352

Sanni L. Aalto

Technical University of Denmark

46 PUBLICATIONS 504 CITATIONS

SEE PROFILE

Some of the authors of this publication are also working on these related projects:

Project $\quad$ MARIGREEN - Sustainable utilization of MARIne resources to foster GREEN plant production in Europe View project

Project BONUS CLEANAQ - Innovative removal of N, P and organic matter in effluents from recirculating aquaculture systems View project 


\title{
Increased sulfate availability in saline water promotes hydrogen sulfide production in fish organic waste
}

\author{
Carlos O. Letelier-Gordo $^{\mathrm{a}, *}$, Sanni L. Aalto ${ }^{\mathrm{a}, \mathrm{b}}$, Suvi Suurnäkki ${ }^{\mathrm{b}}$, Per Bovbjerg Pedersen ${ }^{\mathrm{a}}$ \\ ${ }^{a}$ Technical University of Denmark, DTU Aqua, Section for Aquaculture, The North Sea Research Centre, P.O. Box 101, DK-9850 Hirtshals, Denmark \\ ${ }^{\mathrm{b}}$ University of Jyväskylä, Department of Biological and Environmental Science, P.O. Box 35, 40014 Jyväskylä, Finland
}

\section{A R T I C L E I N F O}

\section{Keywords}

Hydrogen sulfide

Organic matter

Seawater

Sulfate

Sulfate reducing bacteria

\begin{abstract}
A B S T R A C T
The risk of hydrogen sulfide $\left(\mathrm{H}_{2} \mathrm{~S}\right)$ production can be a challenge in marine land-based recirculating aquaculture systems (RAS). Hydrogen sulfide is a toxic gas that can cause massive fish mortality even at low concentrations, and in addition, serious odour problems in the surroundings. It is a bacterial by-product originating from the degradation of organic matter in sulfur-rich waters such as marine waters. In order to hinder $\mathrm{H}_{2} \mathrm{~S}$ production in marine land-based RAS, more information on the $\mathrm{H}_{2} \mathrm{~S}$ production conditions and the associated microbiology is needed. In this study, the production of $\mathrm{H}_{2} \mathrm{~S}$ from rainbow trout (Oncorhynchus mykiss) organic waste was examined using a novel $\mathrm{H}_{2} \mathrm{~S}$ measurement method under a range of salinities $(0,5,10,15,25$ and $35 \mathrm{~g} / \mathrm{L})$ in anaerobic mixed reactors, and the microbial communities as well as abundance of sulfate reducing bacteria (SRB) were characterized. The maximum $\mathrm{H}_{2} \mathrm{~S}$ concentration increased from $23.1 \pm 8.2 \mathrm{mg} \mathrm{H}_{2} \mathrm{~S} / \mathrm{L}$ at $0 \mathrm{~g} / \mathrm{L}$ salinity to $153.9 \pm 34.1 \mathrm{mg} \mathrm{H}_{2} \mathrm{~S} / \mathrm{L}$ at $35 \mathrm{~g} / \mathrm{L}$ salinity. Similarly, the $\mathrm{H}_{2} \mathrm{~S}$ production rate increased from $5.6 \pm 0.2$ at $0 \mathrm{~g} / \mathrm{L}$ salinity to $26.4 \pm 12.7 \mathrm{mg}$ of $\mathrm{H}_{2} \mathrm{~S}$ produced per day at $35 \mathrm{~g} / \mathrm{L}$ salinity. The highest $\mathrm{H}_{2} \mathrm{~S}$ production was recorded after increased availability of volatile fatty acids, which were produced by fermentative bacteria from phyla Firmicutes and Bacteroidetes that dominated the microbial communities after day 5 . The traditional sulfate reducing bacteria (SRB) were found only at 0 and $5 \mathrm{~g} / \mathrm{L}$ salinity, while at higher salinities, $\mathrm{H}_{2} \mathrm{~S}$ production was carried out by novel unquantifiable SRB. The results demonstrate that $\mathrm{H}_{2} \mathrm{~S}$ can be a pronounced problem in marine RAS, although it can be controlled through preventing anaerobic conditions within the system.
\end{abstract}

\section{Introduction}

In the last few years, large-scale marine land-based recirculating aquaculture systems (RAS), producing e.g. Atlantic salmon (Salmo salar) and yellowtail kingfish (Seriola lalandi), have been constructed worldwide (Dalsgaard, 2017). Marine land-based RAS offer high level of bio-security and better control over environmental conditions as compared to the traditional sea cage production, (Martins et al., 2010), resulting in optimal fish growth as well as reduced environmental impact. They are, however, facing a potential challenge in the risk of hydrogen sulfide $\left(\mathrm{H}_{2} \mathrm{~S}\right)$ production within the system. Previously, elevated sulfide concentrations have been found below net cages (Chang et al., 2013; Holmer and Kristensen, 1992). Being a strong chemical asphyxiant, $\mathrm{H}_{2} \mathrm{~S}$ production poses even a more severe threat to fish health and welfare in closed aquaculture systems.

$\mathrm{H}_{2} \mathrm{~S}$ is a colorless flammable gas with a characteristic odor of "rotten eggs" (Arbison and Ourgeois, 2015). It has higher density than air, meaning that it accumulates in the bottom areas rather than dis- persing easily in the air (Abdollahi and Hosseini, 2014). Recently, marine RAS facilities have experienced incidents caused by $\mathrm{H}_{2} \mathrm{~S}$, including mass fish mortality and severe odor problems in the surrounding areas (Dalsgaard, 2019). In fish, $\mathrm{H}_{2} \mathrm{~S}$ has severe consequences, preventing oxygen release, generating cellular anoxia and finally preventing ATP production (Kiemer et al., 1995). Toxicity of $\mathrm{H}_{2} \mathrm{~S}$ towards aquaculture-reared species has not been extensively reported, but $\mathrm{LC}_{50}$ values of $0.013 \mathrm{mg} / \mathrm{L}$ in $48 \mathrm{~h}$ have been found for walleye (Sander vitreus), $0.026 \mathrm{mg} / \mathrm{L}$ in $96 \mathrm{~h}$ for northern pike (Esox Lucius), $0.031 \mathrm{mg} /$ $\mathrm{L}$ in $96 \mathrm{~h}$ for brook trout (Salvelinus fontinalis), $0.030 \mathrm{mg} / \mathrm{L}$ at $72 \mathrm{~h}$ for bluegill (Lepomis macrochirus), $0.007 \mathrm{mg} / \mathrm{L}$ at $96 \mathrm{~h}$ for fathead minnow (Pimephales promelas), and $0.025 \mathrm{mg} / \mathrm{L}$ at $72 \mathrm{~h}$ for goldfish (Carassius auratus) (Smith and Oseid, 1974). Atlantic salmon (Salmo salar) has been suggested to be more tolerant for $\mathrm{H}_{2} \mathrm{~S}$, since a periodic exposure during 18 weeks to $\mathrm{H}_{2} \mathrm{~S}$ concentrations of $0.27 \mathrm{mg} / \mathrm{L}$ did not found to cause significant damage (Kiemer et al., 1995). However, a single acute dose of hydrogen sulfide between 0.75 and $0.99 \mathrm{mg} / \mathrm{L}$ induced considerable stress and gill tissue damage (necrosis), which was sug-

\footnotetext{
* Corresponding author.

E-mail address: colg@aqua.dtu.dk (C.O. Letelier-Gordo)
} 
gested to lead to progressive liver damage, reduced growth and greater susceptibility to diseases.

The main reason for $\mathrm{H}_{2} \mathrm{~S}$ being produced in marine RAS is the high abundance of sulfate in seawater, as marine water has a more complex chemistry with ion concentrations of 10-1000 times higher than in freshwater (Nazaroff and Alvarez-Cohen, 2001). Sulfate is consumed in a dissimilatory sulfate reduction process, where anaerobic sulfate reducing bacteria (SRB) utilize sulfate as electron acceptor for the decomposition of organic matter (Harada et al., 1994; van Loosdrecht et al., 2016). In general, SRB degrade fermentation products like acetate, propionate, butyrate, lactate and hydrogen, which are produced from complex organic molecules by fermentative bacteria. The-end products of sulfate reduction process are bisulfide $\left(\mathrm{HS}^{-}\right)$and hydrogen sulfide $\left(\mathrm{H}_{2} \mathrm{~S}\right)$ (Gerardi, 2006). The quantity of $\mathrm{H}_{2} \mathrm{~S}$, the form that escapes to the atmosphere, depends on the $\mathrm{pH}$ of the water, initial dissolved hydrogen sulfide concentration, and temperature (Eaton et al., 1995). The sulfide production rates of SRB depend on e.g. $\mathrm{pH}$, temperature, sulfate concentrations, and organic matter bioavailability (Laanbroek and Pfennig, 1981; Muyzer and Stams, 2008; Plugge et al., 2011). Although sulfate reduction capacity is found within nine bacterial and archaeal phyla (Müller et al., 2015), the most commonly found SRB belong to $\sim 23$ deltaproteobacterial genera (e.g. Desulfobulbaceae, Desulfovibrionaceae; Muyzer and Stams, 2008). SRB are abundant in sulfate-rich sea sediments, but are also common in wastewater treatment plants and in other engineered environments with high sulfate waters and organic matter concentrations (EPA, 1991; Hao et al., 2014; Zhang et al., 2008). Even though $\mathrm{H}_{2} \mathrm{~S}$ production has been observed below the fish cages (Chang et al., 2013; Holmer et al., 2005; Holmer and Kristensen, 1992), the identity and function of microbes involved in $\mathrm{H}_{2} \mathrm{~S}$ production in aquaculture environments has not yet been adequately described.

Despite the high operational and economic risks associated with $\mathrm{H}_{2} \mathrm{~S}$ in the aquaculture sector, the knowledge on the $\mathrm{H}_{2} \mathrm{~S}$ production and the causative microbiology is limited. The following study aims to: 1) test and evaluate the reliability of a $\mathrm{H}_{2} \mathrm{~S}$ measurement method for RAS water and sludge samples, 2) evaluate the production dynamics, rates and maximal values of $\mathrm{H}_{2} \mathrm{~S}$ obtained from fish organic waste at different salinities (0, 5, 10, 15, 25 and $35 \mathrm{~g} / \mathrm{L})$, and 3 ) examine the microbial community associated to the process.

\section{Materials and methods}

\subsection{Fish organic waste collection}

Rainbow trout (Oncorhynchus mykiss) was reared in six different salinities $(0,5,10,15,25$ and $35 \mathrm{~g} / \mathrm{L})$ in $1 \mathrm{~m}^{3}$ rectangular tanks under a flow-through system. The fish were stocked at a density of $20 \mathrm{~kg}$ fish $\mathrm{m}^{3}$ and daily fed $1 \%$ of the biomass ( $200 \mathrm{~g} / \mathrm{d}$ with a $12 \mathrm{~h}$ autofeeder), using Biomar Enviro 920 (Biomar A/S, Denmark), salinity was continuously monitored with a Seawater Refractometer (HI 96822, Hanna Instruments, US). Samples of fish organic waste produced during $24 \mathrm{~h}$ were collected at the bottom of $20 \mathrm{~L}$ swirl separators with a $2 \mathrm{~L}$ collectors and stored at $4{ }^{\circ} \mathrm{C}$. Samples from two consecutive days were pooled for the $\mathrm{H}_{2} \mathrm{~S}$ production experiments.

\subsection{Experimental design and sampling}

To evaluate the production of $\mathrm{H}_{2} \mathrm{~S}$, the fish organic waste from the six different salinities were transferred into $2 \mathrm{~L}$ enclosed Blue Cap bottles (SCHOTT Duran, Germany) serving as anaerobic batch reactors. The reactors were kept at room temperature $\left(19.6 \pm 1.4^{\circ} \mathrm{C}\right)$ with continuous magnetic stirring at $200 \mathrm{rpm}$ (Big Squid, IKA, Germany). The bottles were sealed with screw caps with two ports for sampling purposes (cap GL, Duran Group, Germany), designed to avoid potential oxygen interference. The data was collected during two separate ex- periments, each lasting for 25 days. The first experiment examined salinities of $0,15,25$ and $35 \mathrm{~g} / \mathrm{L}$, and the second experiment salinities of 0 , 5, 10 and $35 \mathrm{~g} / \mathrm{L}$. Before starting the experiment all reactors were spiked with sodium nitrate (VWR, Denmark) to a final concentration of $50 \mathrm{mg}$ $\mathrm{NO}_{3}{ }^{-}$-N/L, to ensure that possible VFAs were consumed through denitrification as has been reported by Suhr et al. (2013). A sample (50 mL) for analysis of soluble chemical oxygen demand (sCOD), volatile fatty acids (VFAs), and total dissolved sulfide (TDS) was taken every two days. At the same time, $\mathrm{pH}$ and temperature were measured using a portable meter (Hach HQ40d, Hach Lange, Germany). Total chemical oxygen demand (TCOD) in each reactor was analyzed at the start of the experimental period (day 0). In experiment 2, an additional $1.5 \mathrm{~mL}$ sample was taken for microbiological analysis on day $0,1,3,5,10$ and 20.

\subsection{Chemical analysis}

Samples for sCOD and VFA were centrifuged at $4500 \mathrm{rpm}$ for $15 \mathrm{~min}$ at sample temperature, and supernatants were filtered with $0.2 \mu \mathrm{m}$ syringe filters Filtropur S, SARSTEDT, Germany. The filtered samples for SCOD, and VFA, as well as unfiltered samples for TCOD were subsequently preserved by adding $1 \% \mathrm{v} / \mathrm{v}$ of sulfuric acid ( $4 \mathrm{~mol} / \mathrm{L} \mathrm{H}_{2} \mathrm{SO}_{4}$, Merck Millipore, Germany), and maintained at $+4{ }^{\circ} \mathrm{C}$ until analysis. VFAs were analyzed using a 930 Compact IC Flex 1 with a Metrosep A Supp $7-250 / 4.0$ column coupled with a 887 Professional UV/VIS detector (Metrohm, Sweden), and $0.1 \mathrm{M} \mathrm{H}_{2} \mathrm{SO}_{4}$ was used as suppressor and $3.6 \mathrm{mN} \mathrm{Na} \mathrm{CO}_{3}$ as eluent. The determination of TCOD and sCOD was performed using digestion vials LCK 514 and LCK 314, respectively (Hach Lange, Germany). Total dissolved sulfide concentration $\left(\mathrm{S}^{2-}\right)$ was analyzed using a modified methylene blue method, "Sulfulla" (see Supplementary material). In addition, $\mathrm{pH}$, temperature and salinity of the sample were recorded for estimating the $\mathrm{H}_{2} \mathrm{~S}$ fraction according to Eaton et al. (1995).

\subsection{Microbiological analysis}

Immediately after sampling, microbiological samples were frozen and stored at $-20{ }^{\circ} \mathrm{C}$. Before DNA extraction, samples were centrifuged at $10,000 \mathrm{~g}$ for $1 \mathrm{~min}$, and supernatant was removed. DNA was extracted


Germany) according to the manufacturer's instructions. PowerLyzer Homogenizer was applied once, 3,400 rpm for $45 \mathrm{~s}$, during the extraction. The quantity of extracted DNA was measured with Qubit ${ }^{\mathrm{TM}}$ dsDNA HS assay and Qubit 2.0 Fluorometer (Thermo Fisher Scientific, US).

In order to quantify the abundance of sulfate reducing microbes, qPCR quantifications were performed using primer pairs targeting the two key enzymes of sulfate reduction pathway: dissimilatory sulfite reductase (dsrA; RH1-dsr-F/RH3-dsr-R; Ben-Dov et al., 2007) and the dissimilatory adenosine-5'-phospho-sulfate reductase (aps; RH1-aps-F/ RH2-aps-R; Ben-Dov et al., 2007). Both qPCR reactions included $5 \mathrm{ng}$ of template DNA, $0.2 \mu \mathrm{M}$ forward and reverse primers, and 1x Maxima SYBR Green/Fluorescein Master Mix (Thermo Fisher) in a total volume of $25 \mu$ l. The thermal conditions were as follows: initial denaturation $10 \mathrm{~min} 95^{\circ} \mathrm{C}$, then 40 cycles at $95{ }^{\circ} \mathrm{C}$ for $15 \mathrm{~s}, 60{ }^{\circ} \mathrm{C}$ for $60 \mathrm{~s}$ and $72{ }^{\circ} \mathrm{C}$ for $30 \mathrm{~s}$. Amplification efficiencies were between 88-93\% for the qPCR assays. The quantification was performed using CFX96 qPCR thermal cycler (Bio-Rad, US).

Microbial community composition was studied using next generation sequencing targeting V4 region of $16 \mathrm{~s}$ rRNA gene with primers 515F-Y (Parada et al., 2016) and 806R (Caporaso et al., 2011) and the analysis of gene sequences was done using mothur (version 1.39.5; Schloss et al., 2009) as in von Ahnen et al. (2019). Before calculating alpha and beta diversities, the data was normalized by subsam- 
pling to 15,866 sequences. Sequences have been submitted to NCBI Sequence Read Archive under BioProject PRJNA562807.

\subsection{Statistical and data analysis}

The statistical analysis was carried out using the open-source software $\mathrm{R}$ (version 3.5.3; R Core Team, 2016) and figures were created using packages "ggplot" (Wickham, 2016), "dplyr" (Wickham et al., 2019), and "tidyr" (Wickham and Henry, 2019).Since data was normally distributed, a one-way ANOVA analysis followed by a Tukey-Kramer multiple comparison test was used to test for significant differences between the maximum $\mathrm{H}_{2} \mathrm{~S}$ concentration and normalized maximal $\mathrm{H}_{2} \mathrm{~S}$ production between salinity treatments.

$\mathrm{H}_{2} \mathrm{~S}$ production rates in the different salinities tested were estimated according to zero and first order kinetic reactions (Nazaroff \& Cohen, 2001). Non-metric multidimensional scaling (NMDS) conducted with metaMDS function in "vegan" package (Oksanen et al., 2013), plots calculated based on Bray-Curtis distance matrix were used to visualize dynamics in the microbial community structure. Before NMDS, Wisconsin and square- root-transformations were applied to OTU abundance data. The relationships between microbial OTU abundance and $\mathrm{H}_{2} \mathrm{~S}$ concentration was studied using Kendall correlation analysis.

\section{Results and discussion}

The amount of fish organic waste collected was rather constant between the tanks, with a final average of $30 \pm 15 \mathrm{~g}$ TCOD/L inside the batch reactors (Table 1 ). However, the reactors at $0 \mathrm{~g} / \mathrm{L}$ salinity in experiment 1 and at $35 \mathrm{~g} / \mathrm{L}$ salinity in experiment 2, had higher TCOD concentration as compared to the other treatments. This can be explained by an increased amount of uneaten pellets found in the collectors, increasing the final collected TCOD concentration, even though fish were fed the same amount in all tanks.

Table 1. Organic matter concentration (total chemical oxygen demand (TCOD g/L; mean $\pm \mathrm{SD}, n=3$ ) in the anaerobic reactors at different salinities in the two experiments at day 0. Samples are based on subsequent pooling for two consecutive days.

\subsection{Effect of salinity and organic matter in $\mathrm{H}_{2} \mathrm{~S}$ production}

Based on the standard curve (see Supplementary material), the "Sulfulla" method showed high accuracy $\left(R^{2}=0.999\right)$ for concentrations ranging between 0 and $1.2 \mathrm{mg} \mathrm{S}^{2-} / \mathrm{L}$, while samples with higher concentrations should be diluted with microfiltrated (MQ) water. The analysis is equally accurate for both RAS water and fish organic waste samples, the latter requiring pre-handling of the sample (see Supplementary material).

Production of $\mathrm{H}_{2} \mathrm{~S}$ was found at all salinity levels. In both experiments, $\mathrm{H}_{2} \mathrm{~S}$ production (concentration $>0.5 \mathrm{mg} / \mathrm{L}$ ) was detected already at day 2. The zero or first order kinetics of $\mathrm{H}_{2} \mathrm{~S}$ production differed slightly between experiments, starting at day 5 in experiment 1 and at day 7 in experiment 2 . In all reactors, $\mathrm{H}_{2} \mathrm{~S}$ accumulated until reaching a maximum concentration (Table 2) to further decrease with time (except $10 \mathrm{~g} / \mathrm{L}$ salinity) (Fig. 1). The reduction of $\mathrm{H}_{2} \mathrm{~S}$ concentration could be due to; $\mathrm{H}_{2} \mathrm{~S}$ oxidation by bacterial sulfide oxidation, chelation in solution by fatty acids produced during the fermentation of the organic matter, precipitation with soluble metals e.g. cadmium, iron and zinc present in seawater, or diffusion to the gas phase (Dague, 1972; Gerardi, 2006; White et al., 1997).

Both the maximum $\mathrm{H}_{2} \mathrm{~S}$ concentration $(\mathrm{r}=0.84, p<0.05)$ and $\mathrm{H}_{2} \mathrm{~S}$ production rates $\left(\mathrm{mg} \mathrm{H}_{2} \mathrm{~S} / \mathrm{d} ; \mathrm{r}=0.83, p<0.05\right)$, calculated according to zero or first order kinetics, increased with increasing salinity (Table 2).

Table 2. Maximum $\mathrm{H}_{2} \mathrm{~S}$ concentration ( $\mathrm{mg} \mathrm{H}_{2} \mathrm{~S} / \mathrm{L}$ ) and $\mathrm{H}_{2} \mathrm{~S}$ production rate $\left(\mathrm{mg} \mathrm{H}_{2} \mathrm{~S} / \mathrm{d}\right)$ from fish organic waste at different salinities $(0,5$, 10, 15, 25 and $35 \mathrm{~g} / \mathrm{L}$ ) (mean $\pm \mathrm{SD}, n=3$ ).

The correlation between salinity and total dissolved sulfide $\left(\mathrm{S}^{2-}\right)$ concentration $(r=0.74, p<0.05)$ was slightly better than the correlation between salinity and $\mathrm{H}_{2} \mathrm{~S}$ concentration $(\mathrm{r}=0.70, \mathrm{p}<0.05)$. This is due to $\mathrm{S}^{2-}$ including both end-products of bacterial sulfate reduction, $\mathrm{H}_{2} \mathrm{~S}$ and bisulfide (HS-). At $35 \mathrm{~g} / \mathrm{L}$ salinity in experiment 1 , the maximum $\mathrm{S}^{2-}$ concentration $(251.0 \pm 23.5 \mathrm{mg} / \mathrm{L})$ was higher than in experiment $2\left(184.1 \pm 65.4 \mathrm{mg} / \mathrm{L}\right.$ of $\left.\mathrm{S}^{2-}\right)$ (Suppl. Figs. 1 and 2$)$. However, the calculated concentration of the unionized form $\left(\mathrm{H}_{2} \mathrm{~S}\right)$, was $7 \%$ higher in experiment 2 than in experiment 1 , because the $\mathrm{pH}$

Table 1

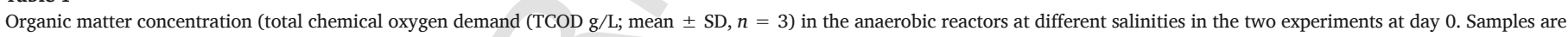
based on subsequent pooling for two consecutive days.

\begin{tabular}{|c|c|c|c|c|c|c|c|}
\hline Salinity (g/L) & & 0 & 5 & 10 & 15 & 25 & 35 \\
\hline \multirow[t]{2}{*}{ TCOD $(\mathrm{g} / \mathrm{L})$} & $\begin{array}{l}\text { Exp. } \\
1\end{array}$ & $44.6 \pm 1.1^{\mathrm{a}}$ & -- & -- & $17.4 \pm 1.1^{\mathrm{d}}$ & $16.2 \pm 0.8^{d}$ & $27.0 \pm 0.6^{c}$ \\
\hline & $\begin{array}{l}\text { Exp. } \\
2\end{array}$ & $23.4 \pm 0.7^{b}$ & $26.2 \pm 1.4^{c}$ & $24.5 \pm 0.4^{b c}$ & -- & -- & $61.8 \pm 0.4^{e}$ \\
\hline
\end{tabular}

Values not sharing a common superscript letter were significantly different (Tukey-Kramer, $\mathrm{P}<0.05$ ).

Table 2

Maximum $\mathrm{H}_{2} \mathrm{~S}$ concentration ( $\left.\mathrm{mg} \mathrm{H}_{2} \mathrm{~S} / \mathrm{L}\right)$ and $\mathrm{H}_{2} \mathrm{~S}$ production rate $\left(\mathrm{mg} \mathrm{H}_{2} \mathrm{~S} / \mathrm{d}\right)$ from fish organic waste at different salinities $(0,5,10,15,25$ and $35 \mathrm{~g} / \mathrm{L})(\mathrm{mean} \pm \mathrm{SD}, n=3)$.

\begin{tabular}{|c|c|c|c|c|c|c|}
\hline & 0 & 5 & 10 & 15 & 25 & 35 \\
\hline \multicolumn{7}{|l|}{$\mathrm{H}_{2} \mathrm{~S}$ concentration } \\
\hline Experiment $1\left(\mathrm{mg} \mathrm{H}_{2} \mathrm{~S} / \mathrm{L}\right)$ & $30.3 \pm 1.7$ & & & $124.5 \pm 6.5$ & $93.8 \pm 41.2$ & $148.8 \pm 10.9$ \\
\hline Experiment $2\left(\mathrm{mg} \mathrm{H}_{2} \mathrm{~S} / \mathrm{L}\right)$ & $15.9 \pm 3.2$ & $55.5 \pm 2.4$ & $70.3 \pm 39.3$ & & & $159.1 \pm 52.0$ \\
\hline \multicolumn{7}{|l|}{$\mathrm{H}_{2} \mathrm{~S}$ production rate } \\
\hline Experiment $1\left(\mathrm{mg} \mathrm{H}_{2} \mathrm{~S} / \mathrm{d}\right)$ & $5.6 \pm 0.2^{\mathrm{a}}$ & & & $21.0 \pm 2.3^{b}$ & $14.6 \pm 4.5^{\mathrm{a}}$ & $26.5 \pm 1.3^{b}$ \\
\hline Experiment $2\left(\mathrm{mg} \mathrm{H}_{2} \mathrm{~S} / \mathrm{d}\right)$ & $3.1 \pm 0.7^{b}$ & $7.0 \pm 2.2^{\mathrm{a}}$ & $4.0 \pm 1.6^{b}$ & & & $26.4 \pm 12.7^{\mathrm{a}}$ \\
\hline
\end{tabular}

In superscripts, ${ }^{\mathrm{a}}$ denotes for zero order and ${ }^{\mathrm{b}}$ for first order production kinetics. 


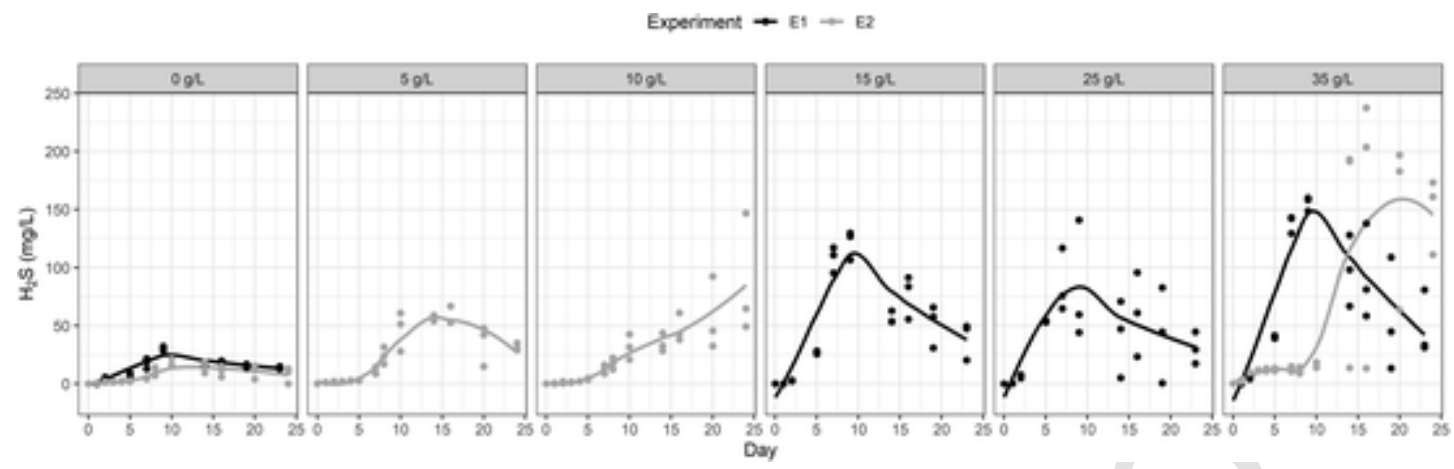

Fig. 1. Concentration of $\mathrm{H}_{2} \mathrm{~S}$ over time at different salinities $(0,5,10,15,25$ and $35 \mathrm{~g} / \mathrm{L})$.

was lower in experiment $2(6.0 \pm 0.2)$ than in experiment 1 $(6.8 \pm 0.3)$. Leading to the higher proportion of $S^{2-}$ being present as $\mathrm{H}_{2} \mathrm{~S}$ in experiment 2. This demonstrates that reporting $\mathrm{H}_{2} \mathrm{~S}$ values as $\mathrm{S}^{2-}$, and not as calculated unionized $\mathrm{H}_{2} \mathrm{~S}$, can lead to too small erroneous estimates, which can have severe consequences in RAS, since even $\mathrm{H}_{2} \mathrm{~S}$ concentrations as low as $0.02 \mathrm{mg} / \mathrm{L}$ can have negative effects on fish health (Adelman and Smith, 1972; Kiemer et al., 1995; Oseid and Smith, 1974; Smith et al., 1976; Smith and Oseid, 1972).

As the initial TCOD i.e. organic matter used at the start of each experiment varied between reactors, the maximum $\mathrm{H}_{2} \mathrm{~S}$ concentrations were normalized with TCOD, expressing the amount of $\mathrm{H}_{2} \mathrm{~S}$ produced per gram of TCOD i.e. organic matter in each reactor (Fig. 2).

The maximum normalized $\mathrm{H}_{2} \mathrm{~S}$ concentration ( $0.68 \mathrm{mg} \mathrm{H}_{2} \mathrm{~S} / \mathrm{g}$ TCOD) was lower at $0 \mathrm{~g} / \mathrm{L}$ salinity (Tukey-Kramer, $p<0.05$ ), while no significant differences were found between the higher salinities (10, 15, 25 and $35 \mathrm{~g} / \mathrm{L}$ ). The correlation between maximum normalized $\mathrm{H}_{2} \mathrm{~S}$ concentration and salinity $(\mathrm{r}=0.32, p<0.05)$ was weaker as com- pared to the one between non-normalized $\mathrm{H}_{2} \mathrm{~S}$ concentration and salinity $(r=0.70, p<0.05)$. This indicates that salinity or the amount of sulfate present in water (ranging from $37.0 \pm 8.4 \mathrm{mg} / \mathrm{L} \mathrm{SO}_{4}{ }^{-} \mathrm{S}$ at $0 \mathrm{~g} / \mathrm{L}$ salinity to $924.4 \pm 61.9 \mathrm{mg} / \mathrm{L} \mathrm{SO}_{4}{ }^{-} \mathrm{S}$ at $35 \mathrm{~g} / \mathrm{L}$ salinity) had a stronger effect on $\mathrm{H}_{2} \mathrm{~S}$ production than the total organic matter (TCOD) present in the reactors. This result can be explained with TCOD not reflecting the amount of electron donors (VFAs), leading to the differences in the availability of electron acceptors and donors. While $\mathrm{SO}_{4}{ }^{-}$ (the electron acceptor for SBR) is readily available, the concentration increasing with salinity, organic matter is present in complex forms that need to go through hydrolysis and fermentation processes to be available as electron donors for SRB (Henze et al., 1997; Ucisik and Henze, 2008). In RAS, fish organic waste, submitted to an anaerobic environment (nitrate depleted), will be hydrolyzed and fermented into formate, acetate, propionate, butyrate and valerate (Aboutboul et al., 1995; Letelier-Gordo et al., 2017), the highest solubilization rates being reached around 5-7 days (Conroy and Couturier, 2010; Lete-

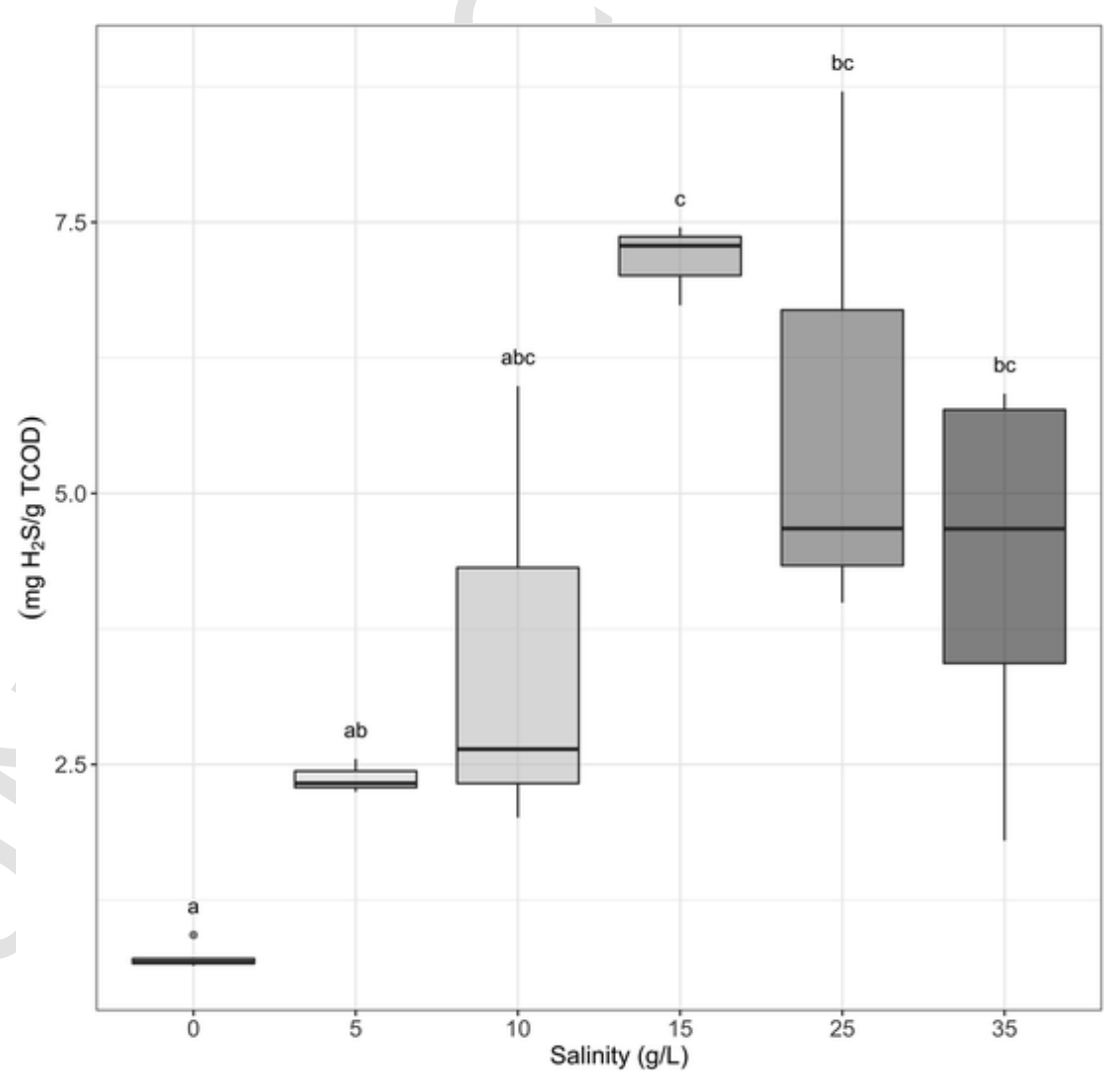

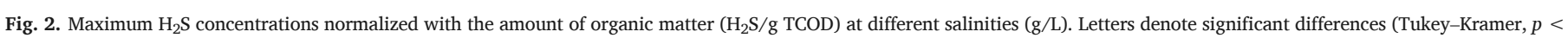
0.05). 
lier-Gordo et al., 2015; Suhr et al., 2013, 2015). This means that once hydrolyzed and fermented, fish organic waste will provide electron donors (VFAs) for SBR, which will result in the production of $\mathrm{H}_{2} \mathrm{~S}$ and consumption of $\mathrm{SO}_{4}{ }^{-}$-S. Indeed, in this experiment at $35 \mathrm{~g} / \mathrm{L}$ salinity, VFA concentrations started to increase after 5 days, leading to the increasing $\mathrm{H}_{2} \mathrm{~S}$ and decreasing $\mathrm{SO}_{4}{ }^{-}-\mathrm{S}$ concentration after 10 days (Fig. $3)$. This situation can eventually occur in rearing tanks with low removal of solids or in pipes with high biofilm growth, as has been observed in municipal sewers (Hvitved-Jacobsen et al., 2002; Lahav et al., 2004; Liu et al., 2015), or in biofilters, where organic matter can build up (Nootong and Powtongsook, 2012). In this study, the maximum obtained $\mathrm{H}_{2} \mathrm{~S}$ concentration was $7.21 \pm 0.8 \mathrm{mg} \mathrm{H} \mathrm{H}_{2} \mathrm{~S} / \mathrm{g}$ TCOD at $15 \mathrm{~g} / \mathrm{L}$ salinity, meaning that one $\mathrm{kg}$ of organic matter submitted to anaerobic conditions has the potential to produce $7.2 \mathrm{~g} \mathrm{H}_{2} \mathrm{~S}$. When assuming that a marine land-based RAS uses $700 \mathrm{~m}^{3}$ tanks, $1 \mathrm{~kg}$ of organic matter will in a worst-case scenario produce of $0.01 \mathrm{mg} \mathrm{H}_{2} \mathrm{~S} / \mathrm{L}$, a concentration that is already dangerous for fish.

\subsection{Effect of salinity on the microbial community and sulfate reducing bacteria}

The overall microbial community, measured in experiment 2, changed gradually in time and between salinities, the communities at $35 \mathrm{~g} / \mathrm{L}$ being significantly different than communities at $0 \mathrm{~g} / \mathrm{L}$ and the other tested salinities (Suppl. Fig. 3). In the beginning of the experiment, Proteobacteria was the most common phyla in all salinities, but the relative abundance decreased steadily during the experiment. This group disappeared completely at $35 \mathrm{~g} / \mathrm{L}$ salinity between days 3 and 20 (Fig. 4). The most abundant proteobacterial families were faculta-
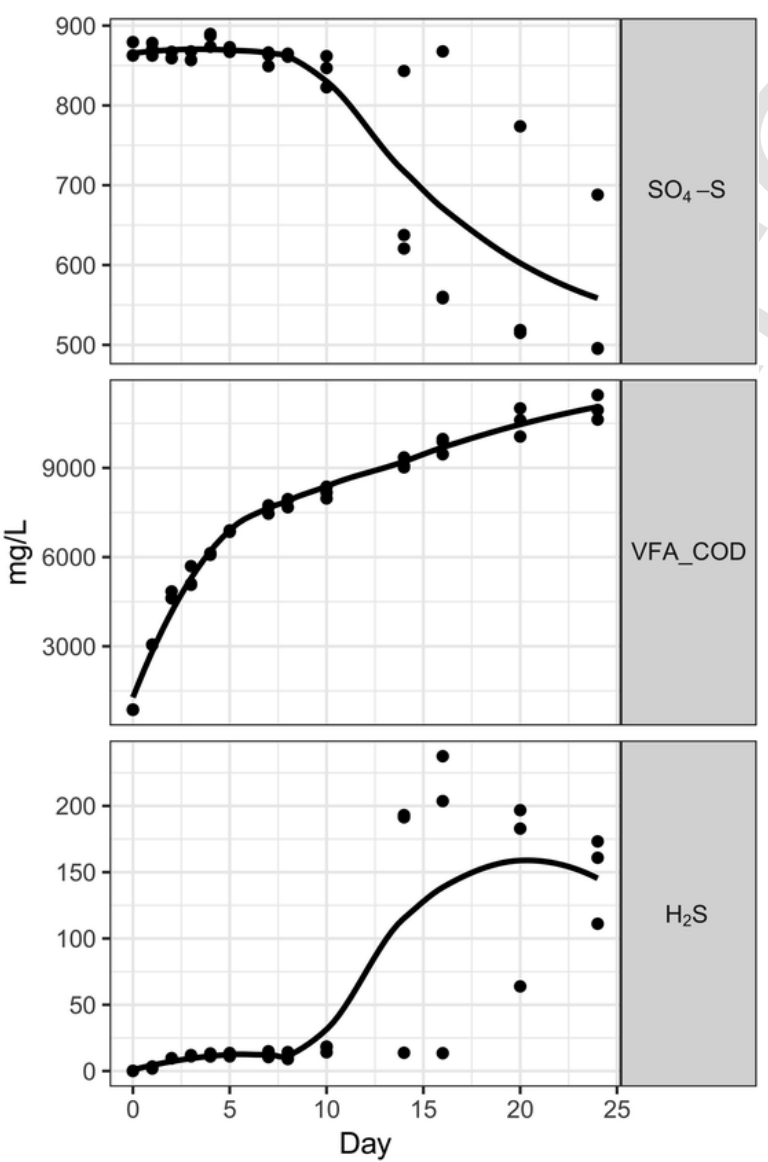

Fig. 3. Sulfate, VFA dynamics and $\mathrm{H}_{2} \mathrm{~S}$ found in the $35 \mathrm{~g} / \mathrm{L}$ salinity anaerobic reactor in the experiment 2 . tive anaerobic gammaproteobacterial Aeromonadaceae, Enterobacteriaceae and Vibrionaceae, which probably originated from rainbow trout intestines (Kim et al., 2007), and decreased when conditions became strictly anaerobic. The abundance of Bacteroidetes and/or Firmicutes increased with time in all salinities, representing $>50 \%$ of microbial community after day 3. Both phyla include important obligatory anaerobes involved in the fermentation of organic matter, such as orders Lactobacillales, Clostridiales and Bacteroidales, that could thrive only when oxygen was depleted in the reactors and be responsible for the VFA production observed after day 5. The common SRB from Deltaproteobacteria were found in significant abundances ( $0.1-6 \%$ of total reads) only in $0 \mathrm{~g} / \mathrm{L}$ and $5 \mathrm{~g} / \mathrm{L}$ salinity reactors (data not shown).

Altogether, the abundance of 23 OTUs correlated positively with $\mathrm{H}_{2} \mathrm{~S}$ concentration, but the correlation pattern was not equal between the salinities, reflecting the differences in the abundance of these OTUs (Suppl. Table 1). Only members of family Ruminococcaceae from Firmicutes (OTU27, 28, 39, 48) were found to correlate with $\mathrm{H}_{2} \mathrm{~S}$ at all salinities. This family has not been found to take part in sulfide production, but is a common fermenter that became abundant towards the end of the experiment when concentrations of VFAs also increased. At 0 and $5 \mathrm{~g} / \mathrm{L}$ salinity, the abundance of the common SRB, deltaproteobacterial Desulfovibrio (OTU23), increased with $\mathrm{H}_{2} \mathrm{~S}$, while being completely absent at the higher salinities. At low salinities (0, 5 and $10 \mathrm{~g} / \mathrm{L})$, the abundance of several OTUs assigned to genera Bacteroides and Macellibacteroides from phylum Bacteroidetes (OTU6, 11, 19, 33), as well as the abundance of gammaproteobacterial genus Acinetobacter (OTU18, 35 ) and of family Lachnospiraceae from phylum Firmicutes (OTU22, 25, 38) increased with $\mathrm{H}_{2} \mathrm{~S}$ concentration. Since both Bacteroidetes and Lachnospiraceae are considered as common fermenters, the correlation describes more increased fermentation than $\mathrm{H}_{2} \mathrm{~S}$ production, as the abundance of OTUs assigned to this phylum correlated also positively with VFA concentrations (data not shown). However, Acinetobacter has been identified to be involved in $\mathrm{H}_{2} \mathrm{~S}$ metabolism (Luo et al., 2013), suggesting that there was some sulfide consumption happening when the concentration increased. At 10 and $35 \mathrm{~g} / \mathrm{L}$ salinity, high $\mathrm{H}_{2} \mathrm{~S}$ concentration coincided with the high abundance of Fusobacterium (OTU9). The physiology of this group is not well established, but it has been found to possess at least four enzymes related to the alternative $\mathrm{H}_{2} \mathrm{~S}$ production pathways, degrading aminoacids e.g. L-cysteine and peptides into $\mathrm{H}_{2} \mathrm{~S}$ (Basic et al., 2017) and to possess anaerobic sulfite reductase (asr) (Anantharaman et al., 2018) instead of traditional dissimilatory sulfite reductase (dsr) that was quantified in this study. At $35 \mathrm{~g} / \mathrm{L}$ salinity, several OTUs not found in the lower salinities increased with $\mathrm{H}_{2} \mathrm{~S}$ concentration: Firmicutes family Peptostreptococcaceae (OTU16), gammaproteobacterial Marinobacterium (OTU60) and Marinobacter (OTU133), and two OTUs with unidentified taxonomy (OTU90, 219). None of the identified taxa has known connection to sulfur metabolism, although Peptostreptococcaceae was recently found to be abundant in sulfidic streams (Hotaling et al., 2019), suggesting that it might participate to $\mathrm{H}_{2} \mathrm{~S}$ metabolism.

Total microbial abundance measured as the copy numbers of $16 \mathrm{~S}$ rRNA gene increased steadily from the day 0 (Fig. 5a). In $35 \mathrm{~g} / \mathrm{L}$ salinity reactors, the abundance was very high in the beginning, but decreased significantly already after day 1 . Furthermore, the abundance stayed 10-100 times lower at $35 \mathrm{~g} / \mathrm{L}$ salinity than in other reactors, although increasing towards the end of the experiment, reflecting the highly selecting conditions in the most saline reactors. The abundance of the two main marker genes for sulfate reduction, $d s r$ A gene coding for sulfite reductase enzyme and aps gene coding for adenosine 5'-phosphosulfate reductase gene, increased towards the end of the experiment (Fig. 5b, c). The abundance of both genes was highest at $0 \mathrm{~g} / \mathrm{L}$ and $5 \mathrm{~g} / \mathrm{L}$ salinity treatments, although they exhibited lower $\mathrm{H}_{2} \mathrm{~S}$ production than 10 and $35 \mathrm{~g} / \mathrm{L}$ salinity reactors. This result cannot explained with the lower total microbial abundance in the higher salinity treat- 


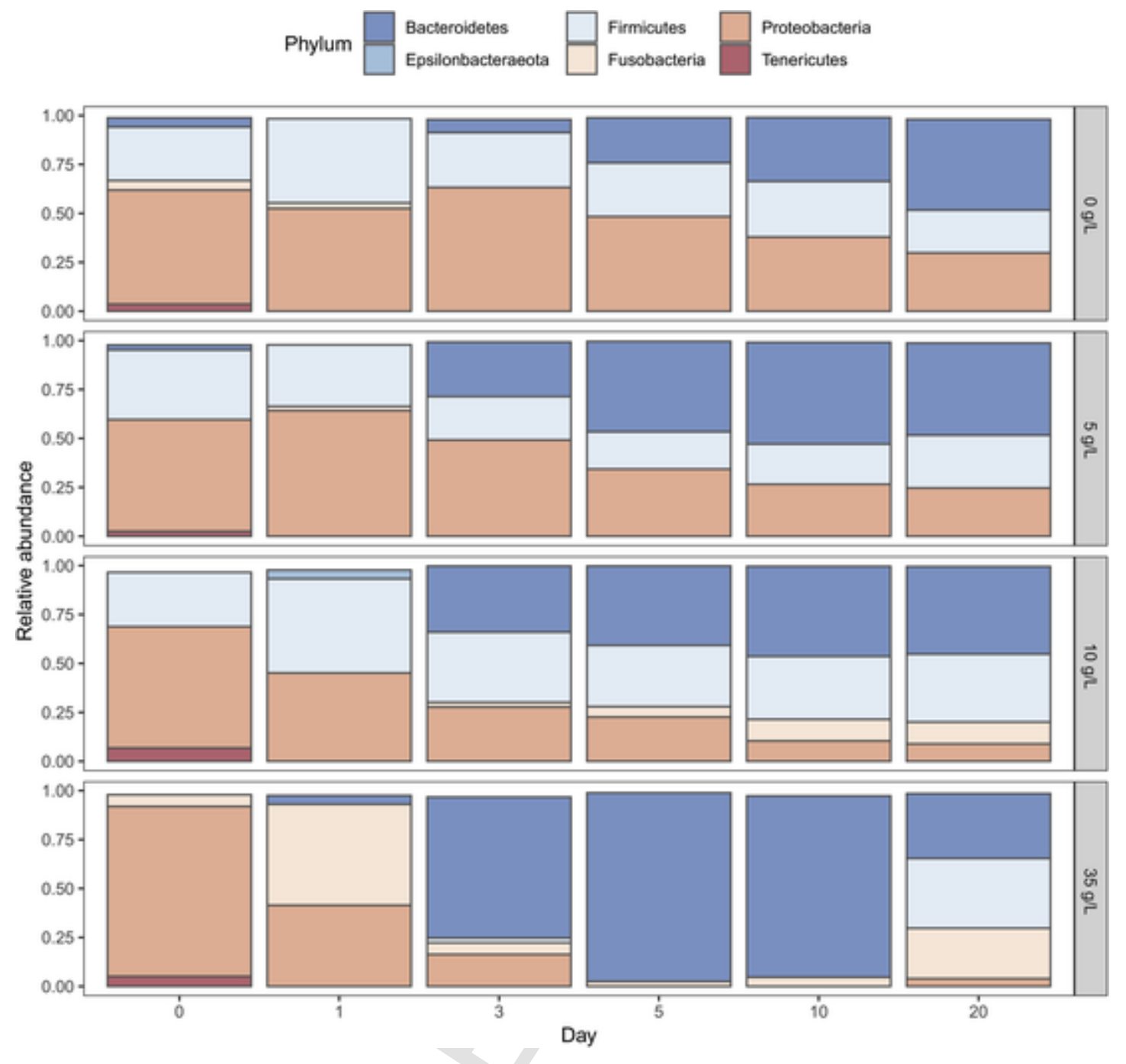

Fig. 4. The relative abundance of bacterial phyla in reactors at different salinities during 20 days of experiment 2.

ments, as the relative abundances ( $d s r \mathrm{~A}$ or aps gene copy number normalized with total microbial abundance) exhibited a similar pattern (data not shown). Since the traditional SRB groups were not found in 10 and $35 \mathrm{~g} / \mathrm{L}$ salinity reactors, it is possible that the SRB present represents novel groups that are not covered by the current primer sets or that they produce $\mathrm{H}_{2} \mathrm{~S}$ through alternative pathways with enzymes that were not quantified here. Based on the correlation analysis results, these novel unquantifiable SRB could belong to Fusobacteria that was abundant both in 10 and $35 \mathrm{~g} / \mathrm{L}$ salinity reactors, or to Firmicutes family Peptostreptococcaceae, or be currently completely unidentified. This means that the SRB abundance cannot be reliable estimated within marine land-based RAS at the moment. Further microbiological research is needed to solve the main $\mathrm{H}_{2} \mathrm{~S}$ production pathways under high salinity in order to develop methods to prevent $\mathrm{H}_{2} \mathrm{~S}$ production when treating saline fish organic waste. When relating the abundance of SRB to $\mathrm{H}_{2} \mathrm{~S}$ produced, it was found that one SRB (one dsrA gene copy; Müller et al., 2015) could produce $1.6 * 10^{-8} \pm 2.9 * 10^{-9} \mathrm{mg} \mathrm{H} \mathrm{H}_{2} \mathrm{~S}$ at $0 \mathrm{~g} / \mathrm{L}$ salinity, and $2.6^{*} 10^{-8} \pm 8.3^{*} 10^{-9} \mathrm{mg} \mathrm{H}_{2} \mathrm{~S} d s r \mathrm{~A}$ at $5 \mathrm{~g} / \mathrm{L}$ salinity during the maximum $\mathrm{H}_{2} \mathrm{~S}$ production.

\section{Conclusions}

This study fills up essential knowledge gaps, providing a reliable method to analyze $\mathrm{H}_{2} \mathrm{~S}$ and new information required for understand- ing $\mathrm{H}_{2} \mathrm{~S}$ production in aquaculture systems. Altogether, the results demonstrate that salinity or mainly the sulfate contained in it, increases $\mathrm{H}_{2} \mathrm{~S}$ production creating a potential problem in marine land-based RAS, but also in the bottom of marine sea cages. The microbiological results indicate that the problem is presumably manageable, since SRB are dependent on the readily available carbon sources produced by slow-growing fermentative bacteria, both groups requiring oxygen-free habitat conditions. This means that implementing frequent cleaning protocols for pipes, tanks, and biofilters, and an efficient system design to avoid organic matter accumulation could limit the production of suitable carbon sources, and thus growth of SRB, and hinder $\mathrm{H}_{2} \mathrm{~S}$ production. Once produced, $\mathrm{H}_{2} \mathrm{~S}$ concentration could also be reduced with nitrate addition (Torun et al., 2020), but it is not an environmentally sustainable approach, as the main effort of the marine land-based RAS technology is to reduce nitrogen discharge. However, in order to develop and test preventive and responsive measures to reduce the risks associated with $\mathrm{H}_{2} \mathrm{~S}$ in marine RAS, more studies on acute $\mathrm{H}_{2} \mathrm{~S}$ toxicity to fish, and the different microbiological $\mathrm{H}_{2} \mathrm{~S}$ production routes are needed.

\section{Uncited references}

, and Wickham (2016). 




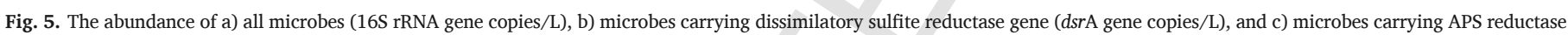
gene (aps gene copies/L) in reactors at four different salinities during 20 days of experiment. Notice different scale in panel a.

\section{Declaration of Competing Interest}

The authors declare that they have no known competing financial interests or personal relationships that could have appeared to influence the work reported in this paper.

\section{Acknowledgments}

The study was funded by BONUS (Art 185), funded jointly by the EU and national funding institutions of Finland (Academy of Finland), Sweden (Vinnova) and Denmark (Innovation Fund Denmark IFD).

The technical skills and invaluable assistance of Ulla Sproegel, Brian Møller, Ole Madvig Larsen and Rasmus Frydenlund Jensen (DTU Aqua) is highly appreciated. We also want to sincerely thank Dr. Esther Savina for providing her expertise on the modelling and graphical presentations of the data in $\mathrm{R}$.

\section{Appendix A. Supplementary data}

Supplementary material related to this article can be found, in the online version, at doi:https://doi.org/10.1016/j.aquaeng.2020.102062.

\section{References}

Abdollahi, M., Hosseini, A., 2014. Hydrogen sulfide. Encycl. Toxicol. Third Ed. 971-974. doi:10.1016/B978-0-12-386454-3.00513-3.

Aboutboul, Y., Arviv, R., van Rijn, J., 1995. Anaerobic treatment of intensive fish culture effluents: volatile fatty acid mediated denitrification. Aquaculture 133, 21-32. doi:10.1016/0044-8486(94)00385-2.

Adelman, I.R., Smith, L.L., Jr., 1972. Toxicity of hydrogen sulfide to goldfish (Carassius auratus) as influenced by temperature, oxygen, and bioassay techniques. J. Fish. Res. Board Canada 29, 1309-1317. doi:10.1139/f72-199.

Anantharaman, K., Hausmann, B., Jungbluth, S.P., Kantor, R.S., Lavy, A., Warren, L.A., Rappé, M.S., Pester, M., Loy, A., Thomas, B.C., Banfield, J.F., 2018. Expanded diversity of microbial groups that shape the dissimilatory sulfur cycle. ISME J. 12, 1715-1728. doi:10.1038/s41396-018-0078-0.
Arbison, S.T.C.H., Ourgeois, J.A.R.B., 2015. Hamilton \& Hardy's Industrial Toxicology. pp. 325-330.

Basic, A., Blomqvist, M., Dahlén, G., Svensäter, G., 2017. The proteins of Fusobacterium spp. involved in hydrogen sulfide production from L-cysteine. BMC Microbiol. 17, 1-10. doi:10.1186/s12866-017-0967-9.

Ben-Dov, E., Brenner, A., Kushmaro, A., 2007. Quantification of sulfate-reducing bacteria in industrial wastewater, by real-time polymerase chain reaction (PCR) using dsrA and apsA genes. Microb. Ecol. 54, 439-451. doi:10.1007/s00248-007-9233-2.

Caporaso, J.G., Lauber, C.L., Walters, W.A., Berg-Lyons, D., Lozupone, C.A., Turnbaugh, P.J., Fierer, N., Knight, R., 2011. Global patterns of 16S rRNA diversity at a depth of millions of sequences per sample. Proc. Natl. Acad. Sci. U. S. A. 108, 4516-4522. doi:10.1073/pnas.1000080107.

Chang, B., Page, F., Losier, R., 2013. Variables affecting sediment sulfide concentrations in regulatory monitoring at salmon farms in the Bay of Fundy, Canada. Aquac. Environ. Interact. 4, 67-79. doi:10.3354/aei00074.

Conroy, J., Couturier, M., 2010. Dissolution of minerals during hydrolysis of fish waste solids. Aquaculture 298, 220-225. doi:10.1016/j.aquaculture.2009.11.013.

Dague, R.R., 1972. Fundamentals of odor control. Water Pollut. Control Fed. 44, 583-594.

Dalsgaard, J., 2017. In: 4th NordicRAS Workshop on Recirculating Aquaculture Systems Aalborg, Denmark, 12-13 October 2017, Book of Abstracts. National Institute of Aquatic Resources, Hirtshals, Denmark.

Dalsgaard, J., 2019. In: 5 th NordicRAS Workshop on Recirculating Aquaculture Systems. Berlin, Germany, 7-8 October 2019, Book of Abstracts. National Institute of Aquatic Resources, Hirtshals, Denmark.

Eaton, A., Clesceri, L., Greenberg, A., 1995. Standard Methods for the Examination of Water and Wastewater. APHA.

EPA, 1991. Hydrogen Sulfide Corrosion in Wastewater Collection and Treatment Systems.

Gerardi, M.H., 2006. Wastewater Bacteria. John Wiley \& Sons, Inc., Hoboken, NY, USA. doi:10.1002/0471979910.

Hao, T.W., Xiang, P.Y., Mackey, H.R., Chi, K., Lu, H., Chui, H., van Loosdrecht, M.C.M., Chen, G.H., 2014. A review of biological sulfate conversions in wastewater treatment. Water Res. doi:10.1016/j.watres.2014.06.043.

Harada, H., Uemura, S., Momonoi, K., 1994. Interaction between sulfate-reducing bacteria and methane-producing bacteria in UASB reactors fed with low strength wastes containing different levels of sulfate. Water Res. 28, 355-367. doi:10.1016/ 0043-1354(94)90273-9.

Henze, M., Harremoës, P., La Cour, J., Arvin, E., 1997. Wastewater Treatment. Biological; and Chemical Processes. Springer-Verlag Berlin Heidelberg, New York, NY, USA. doi:10.1017/S0025315400038911.

Holmer, M., Kristensen, E., 1992. Impact of marine fish cage farming on metabolism and sulfate reduction of underlying sediments. Mar. Ecol. Prog. Ser. 80, 191-201.

Holmer, M., Wildish, D., Hargrave, B., 2005. Organic enrichment from marine finfish aquaculture and effects on sediment biogeochemical processes. Environ. Effects Mar. Finfish Aquac. 5, 181-206. doi:10.1007/b136010. 
Hotaling, S., Quackenbush, C.R., Bennett-Ponsford, J., New, D.D., Arias-Rodriguez, L., Tobler, M., Kelley, J.L., 2019. Bacterial diversity in replicated hydrogen sulfide-rich streams. Microb. Ecol. 77, 559-573. doi:10.1007/s00248-018-1237-6.

Hvitved-Jacobsen, T., Vollertsen, J., Matos, J.S., 2002. The sewer as a bioreactor - A dry weather approach. Water Sci. Technol. 45, 11-24.

Kiemer, M.C.B., Black, K.D., Lussot, D., Bullock, A.M., Ezzi, I., 1995. The effects of chronic and acute exposure to hydrogen sulphide on Atlantic salmon (Salmo salar L.). Aquaculture 135, 311-327. doi:10.1016/0044-8486(95)01025-4.

Kim, D.H., Brunt, J., Austin, B., 2007. Microbial diversity of intestinal contents and mucus in rainbow trout (Oncorhynchus mykiss). J. Appl. Microbiol. 102, 1654-1664. doi:10.1111/j.1365-2672.2006.03185.x.

Laanbroek, H.J., Pfennig, N., 1981. Oxidation of short-chain fatty acids by sulfate-reducing bacteria in freshwater and in marine sediments. Arch. Microbiol. 128, 330-335. doi:10.1007/BF00422540.

Lahav, O., Lu, Y., Shavit, U., Loewenthal, R.E., 2004. Modeling hydrogen sulfide emission rates in gravity sewage collection systems. J. Environ. Eng. 130, 1382-1389. doi:10.1061/(asce)0733-9372(2004)130:11(1382).

Letelier-Gordo, C.O., Dalsgaard, J., Suhr, K.I., Ekmann, K.S., Pedersen, P.B., 2015. Reducing the dietary protein: energy (P: E) ratio changes solubilization and fermentation of rainbow trout (Oncorhynchus mykiss) faeces. J. Aquac. Eng. Fish. Res. 66, 22-29. doi:10.1016/j.aquaeng.2015.02.002.

Letelier-Gordo, C.O., Larsen, B.K., Dalsgaard, J., Pedersen, P.B., 2017. The composition of readily available carbon sources produced by fermentation of fish faeces is affected by dietary protein:energy ratios. Aquac. Eng. 77, 27-32. doi:10.1016/ j.aquaeng.2017.01.006.

Liu, Y., Ni, B.J., Ganigué, R., Werner, U., Sharma, K.R., Yuan, Z., 2015. Sulfide and methane production in sewer sediments. Water Res. 70, 350-359. doi:10.1016/ j.watres.2014.12.019.

Luo, J., Tian, G., Lin, W., 2013. Enrichment, isolation and identification of sulfur-oxidizing bacteria from sulfide removing bioreactor. J. Environ. Sci. (China) 25, 1393-1399. doi:10.1016/S1001-0742(12)60179-X.

Martins, C.I.M., Eding, E.H., Verdegem, M.C.J., Heinsbroek, L.T.N., Schneider, O., Blancheton, J.P., d'Orbcastel, E.R., Verreth, J., 2010. New developments in recirculating aquaculture systems in Europe: a perspective on environmental sustainability. Aquac. Eng. 43, 83-93. doi:10.1016/j.aquaeng.2010.09.002.

Müller, A.L., Kjeldsen, K.U., Rattei, T., Pester, M., Loy, A., 2015. Phylogenetic and environmental diversity of DsrAB-type dissimilatory (bi)sulfite reductases. ISME J. 9, 1152-1165. doi:10.1038/ismej.2014.208.

Muyzer, G., Stams, A.J.M., 2008. The ecology and biotechnology of sulphate-reducing bacteria. Nat. Rev. Microbiol. 6, 441-454. doi:10.1038/nrmicro1892.

Nazaroff, W.W., Alvarez-Cohen, L., 2001. Environmetal Engineering Science. John Wiley \& Sons, Inc., NY, USA.

Nootong, K., Powtongsook, S., 2012. Performance evaluation of the compact aquaculture system integrating submerged fibrous nitrifying biofilters. Songklanakarin J. Sci. Technol. 34, 53-59.

Oksanen, J., Guillaume, B., Friendly, M., Kindt, R., Legendre, P., McGlinn, D., Minchin, P., O'Hara, R.B., Simpson, G.L., Henry, M., Szoecs, E., Wagner, H., 2013. Package 'vegan'. Community Ecology Package, Version 2 (9). pp. 1-295.

Oseid, D.M., Smith, L.L., 1974. Factors influencing acute toxicity estimates of hydrogen sulfide to freshwater invertebrates. Water Res. 8, 739-746. doi:10.1016/ 0043-1354(74)90018-9.

Parada, A.E., Needham, D.M., Fuhrman, J.A., 2016. Every base matters: assessing small subunit rRNA primers for marine microbiomes with mock communities, time se- ries and global field samples. Environ. Microbiol. 18, 1403-1414. doi:10.1111/ 1462-2920.13023.

Plugge, C.M., Zhang, W., Scholten, J.C.M., Stams, A.J.M., 2011. Metabolic flexibility of sulfate-reducing bacteria. Front. Microbiol. 2, 1-8. doi:10.3389/fmicb.2011.00081.

R Core Team R: a Language and Environment for Statistical ComputingURLR Foundation for Statistical ComputingVienna, Austriahttp://www.R-project.org/2016

Schloss, P.D., Westcott, S.L., Ryabin, T., Hall, J.R., Hartmann, M., Hollister, E.B. Lesniewski, R.A., Oakley, B.B., Parks, D.H., Robinson, C.J., Sahl, J.W., Stres, B., Thallinger, G.G., Van Horn, D.J., Weber, C.F., 2009. Introducing mothur: open-source, platform-independent, community-supported software for describing and comparing microbial communities. Appl. Environ. Microbiol. 75, 7537-7541. doi:10.1128/ AEM.01541-09.

Smith, L.L., Oseid, D.M., 1972. Effects of hydrogen sulfide on fish eggs and fry. Water Res. 6, 711-720. doi:10.1016/0043-1354(72)90186-8.

Smith, L.L., Oseid, D.M., 1974. Effect of hydrogen sulfide on development and survival of eight freshwater fish species. In: The Early Life History of Fish. Springer Berlin Heidelberg, Berlin, Heidelberg, pp. 417-430. doi:10.1007/978-3-642-65852-5_34.

Smith, L.L., Oseid, D.M., Olson, L.E., 1976. Acute and chronic toxicity of hydrogen sulfide to the fathead minnow, Pimephales promelas. Environ. Sci. Technol. 10, 565-568. doi:10.1021/es60117a001.

Suhr, K.I., Pedersen, P.B., Arvin, E., 2013. End-of-pipe denitrification using RAS effluent waste streams: effect of $\mathrm{C} / \mathrm{N}$-ratio and hydraulic retention time. Aquac. Eng. 53, 57-64. doi:10.1016/j.aquaeng.2012.11.005.

Suhr, K.I., Letelier-Gordo, C.O., Lund, I., 2015. Anaerobic digestion of solid waste in RAS: effect of reactor type on the biochemical acidogenic potential (BAP) and assessment of the biochemical methane potential (BMP) by a batch assay. Aquac. Eng. 65, 65-71. doi:10.1016/j.aquaeng.2014.12.005.

Torun, F., Hostins, B., Teske, J., De Schryver, P., Boon, N., De Vrieze, J., 2020. Nitrate amendment to control sulphide accumulation in shrimp ponds. Aquaculture in press.

Ucisik, A.S., Henze, M., 2008. Biological hydrolysis and acidification of sludge under anaerobic conditions: the effect of sludge type and origin on the production and composition of volatile fatty acids. Water Res. 42, 3729-3738. doi:10.1016/ j.watres.2008.06.010.

van Loosdrecht, M.C.M., Nielsen, P.H., Lopez-Vazquez, C.M., Damir, B., 2016. Experimental Methods in Wastewater Treatment. IWA publishing, Alliance House, London, UK.

von Ahnen, M., Aalto, S.L., Suurnäkki, S., Tiirola, M., Pedersen, P.B., 2019. Salinity affects nitrate removal and microbial composition of denitrifying woodchip bioreactors treating recirculating aquaculture system effluents. Aquaculture 504, 182-189. doi:10.1016/j.aquaculture.2019.01.068.

White, C., Sayer, J.A., Gadd, G.M., 1997. Microbial solubilization and immobilization of toxic metals: key biogeochemical processes for treatment of contamination. FEMS Microbiol. Rev. 20, 503-516.

Wickham, H., 2016. ggplot2: Elegant Graphics for Data Analysis. Springer-Verlag, New York.

Wickham, H., François, R., Henry, L., Müller, K., 2019. dplyr: A Grammar of Data Manipulation.. R package version 0.8.3. doi:https://CRAN.R-project.org/package = dplyr.

Wickham, H., Henry, L., 2019. tidyr: Tidy Messy Data.. R package version 1.0.0. doi:https://CRAN.R-project.org/package = tidyr.

Zhang, L., De Schryver, P., De Gusseme, B., De Muynck, W., Boon, N., Verstraete, W., 2008. Chemical and biological technologies for hydrogen sulfide emission control in sewer systems: a review. Water Res. 42, 1-12. doi:10.1016/j.watres.2007.07.013. 